\title{
The Impacts of Conventional Energies on Environmental Degradation : Does Pakistan's Economic and Environmental Model Follows Kuznets Curve?
}

Rafeeque A. Nizamani

Mehran University of Engineering \& Technology

Faheemullah Shaikh

Mehran University of Engineering \& Technology

Abdul Ghafoor Nizamani

Southeast University

Nayyar Hussain Mirjat

Mehran University of Engineering \& Technology

Laveet Kumar ( $\square$ laveet.kumar@faculty.muet.edu.pk)

Mehran University of Engineering \& Technology

Mamdouh El Haj Assad

University of Sharjah

\section{Research Article}

Keywords: Conventional energies, Kuznets curve, Pakistan, Urbanization, Manufacturing, Trade openness

Posted Date: October 25th, 2021

DOI: https://doi.org/10.21203/rs.3.rs-996814/v1

License: (c) (i) This work is licensed under a Creative Commons Attribution 4.0 International License.

Read Full License 


\title{
The impacts of conventional energies on environmental degradation : Does Pakistan's economic and environmental model follows Kuznets curve?
}

\author{
Rafeeque A. Nizamani ${ }^{1}$, Faheemullah Shaikh ${ }^{2}$, Abdul Ghafoor Nizamani ${ }^{3}$, Nayyar H. Mirjat ${ }^{2}$, \\ Laveet Kumar $^{1 *}$, Mamdouh El Haj Assad ${ }^{4}$ \\ ${ }^{1}$ Department of Mechanical Engineering, Mehran University of Engineering and Technology, \\ Jamshoro 76062, Pakistan \\ ${ }^{2}$ Department of Electrical Engineering, Mehran University of Engineering and Technology, \\ Jamshoro 76062, Pakistan \\ ${ }^{3}$ Department of Architecture, Southeast University, 2 Sipailou, Nanjing, 21009, China \\ ${ }^{4}$ Sustainable and Renewable Energy Engineering Department, University of Sharjah, P.O. Box \\ 27272, Sharjah, United Arab Emirates
}

\begin{abstract}
This paper investigates the long-run dynamic association of carbon dioxide emissions and economic progress using the environmental Kuznets curve hypothesis for Pakistan from 1972 to 2019. The other variables used along with the above indicators are urbanization, financial development, manufacturing, oil and gas energy consumptions, and trade openness. The ARDL bounds testing methodology has been used and the results of the bounds testing showed that a $1 \%$ increase in economic growth and financial development would increase $\mathrm{CO}_{2}$ emissions in the country by $4.277 \%$ and $0.0787 \%$, respectively. Urbanization and manufacturing would increase $\mathrm{CO}_{2}$ emissions by $0.648 \%$ and $0.171 \%$, respectively. Oil and gas energy consumption would also increase $\mathrm{CO}_{2}$ emissions by $0.130 \%$ and $0.1935 \%$, respectively. On the other hand, trade openness decreases emissions by $-0.087 \%$ in the long run. Besides, findings confirm the EKC hypothesis with the reversed U-shape relation for per capita $\mathrm{CO}_{2}$ emissions and economic progress. However, the threshold point of the economy is approximately $2735.19 \$$ year per capita, where economic progress can mitigate the impact of pollution lies beyond the study period. Finally, for
\end{abstract}

${ }^{*}$ Corresponding author: laveet.kumar@ faculty.muet.edu.pk (Laveet Kumar) 
policy implications: (i) the government should focus on economic growth by overcoming $\mathrm{CO}_{2}$ emissions as per capita income is scarce. (ii) the control and proper expansion of urban areas and empowering the inhabitants with knowledge and awareness to play their role in mitigating the effects of $\mathrm{CO}_{2}$ emissions on society. (iii) a larger share of alternative energy from biomass, the solar, wind, and other less-polluting energies in the energy need model of the country, and (iv) by establishing advanced technology-based industries in the country for economic growth by controlling the impacts on the environment.

Keywords: Conventional energies; Kuznets curve; Pakistan; Urbanization; Manufacturing; Trade openness

\section{Introduction}

Since the industrial revolution, humans are facing a big challenge in terms of climate change, with experts claiming that carbon dioxide emissions are the primary cause of this change (Baek, 2016). The intergovernmental panel on climate change shows concerns that climatic changes are causing extreme weather events that would wipe out half of the coastal population all around the world(Asian Development Bank (ADB), 2017). The economic losses would be higher than those caused by the first and second world wars in early 1900 to 1950(Ahmad et al., 2017). Statistics of the temperature profile of the world shows that average mean temperature of the world would increase from 1.5 to 2 degree Celsius by 2030(Ahmad et al., 2017) (Lau, Choong and Eng, 2014). According to European Commission reports, carbon dioxide emissions are solely responsible for global warming, and $64 \%$ of these emissions are human-made, and $40 \%$ of these emissions are of post industrialization (Pata, 2018c).

At the initial stage, there is a lack of awareness of possible risks at the outset of economic progress and sophisticated technological expertise to mitigate them (Dinda, 2004). Countries in 
the early stages of development, when poverty is still pervasive, corruption is rampant, and income and revenue streams are limited, with little financing available for environmental awareness and conservation (Panayotou, 1993). Therefore, as a result, economic expansion has harmed the environment, as pollution rises with GDP increase.

The Kuznets curve relationship shows how per capita income changes emissions effectiveness from positive to negative (Kuznets, 1955) (Ahmad et al., 2017). In other words, initially, economic growth raises the pressure on environmental pollution, but after achieving a certain level, a rise in growth reduces this pressure of degradation. However, economic prosperity by itself is a solution to mitigate the emissions. Therefore, the application of EKC is still in debate for developed and developing economies because its nature of outcomes is very much sensitive to several factors and time (Jaunky, 2011).

Kuznets curve hypothesis is applied to see the correlation of per capita growth and environmental degradation. Additionally, the economic growth, several other factors also influence the emissions of $\mathrm{CO} 2$, such as urbanization, financial growth activities, manufacturing, and energy based on fossil fuels. (Pata, 2018a). Along with the income and revenue, there is foreign trade which pollutes the environment in different ways. (i) scale effect shows how economic expansion increases the consumption of fuel, resulting in pollution. (ii) The composition effect explains industrial manufacturing first pollutes the environment by increasing economic activity and letter reduces these effects of pollution by foreign trade with the small manufacturing unit. (iii) The technique effect represents that by incorporating new advanced technological units, with environment-friendly policies capable of reducing the impact. The combinations of these different effects are employed to check the positive and negative influences and the relationship between environmental degradation and foreign trade (Grossman 
and Krueger, 1991) (Hill, Magnani, and Hill, 1955). On environmental pollution, it is evident from the literature that foreign trade affects developing countries negatively, whereas it affects developed countries positively.

Financial development has two effects on pollution: (1) Improve the technical efficiency of energy use, finance environmental protection measures, and reduce expenses, and (2) By increasing foreign direct investment and research and development expenditures (Tamazian, Chousa, and Vadlamannati, 2009). By another researcher, Dasgupta et al. (Dasgupta, Laplante, and Mamingi, 2001) concluded financial development could drive economic growth with increased investments, lessened costs, and energy consumption. However, economic expansion may decrease the quality of the environment and influence it adversely.

Increased emissions from energy use are a result of urbanization. Urbanized regions account for two-thirds of global emissions, with energy-related emissions accounting for $70 \%$ of total emissions (IRENA, 2016)(Rahu et al., 2020)(Nizamani et al., 2021).

Geographically, Pakistan is in the south Asian region, having a diverse landscape with various climatic and environmental conditions. Its economy considers as an emerging economy based on agriculture. In recent years, Pakistan has faced stern challenges of un-seasonal monsoon, draughts, high precipitation rates, and heatwaves. All these issues are concerned with global warming due to greenhouse gas emissions.

According to different studies, the average temperature of Pakistan is increasing and would reach up to $4-6{ }^{\circ} \mathrm{C}$ at the end of this century. The air quality worsens and currently ranks at 153 out of 180 countries. Half of the population would be urbanized by 2025. And above all, the adverse climatic conditions have already caused 14 billion US dollars to the economy and being a 
developing country not in a position to tolerate these losses (Asian Development Bank (ADB), 2017) (Hussain et al., 2020).

The Figures 1 to 4 represent the trends of some chosen indicators of Pakistan from 1972 and 2019 (Bank, 2017) ('BP Statistical Review of World Energy Statistical Review of World' 2019).

Figure illustrates some selected particulates. Figure 1 shows how per capita carbon dioxide emissions are releasing into the environment in Pakistan and, these emissions would increase with stable economic activity. Figure 2 represents the per capita GDP growth scenario of Pakistan with a constant 2010 USD. Figure 3 shows the consumption pattern of noncarbohydrate energy in Pakistan with considerations of oil and gas only, and Figure 4 represents the trends of urban population growth.

Although the economy of Pakistan is growing slowly with many difficulties and challenges, concerned authorities should not eye off the burning issue of climate change, not only knocking on her doors but all around the Globe. This paper comprises of the following sections: Section 2 is literature review, Section 3 describes data model and methods, Section 4 presents the results, and section 5 presents conclusion and policy guidelines.

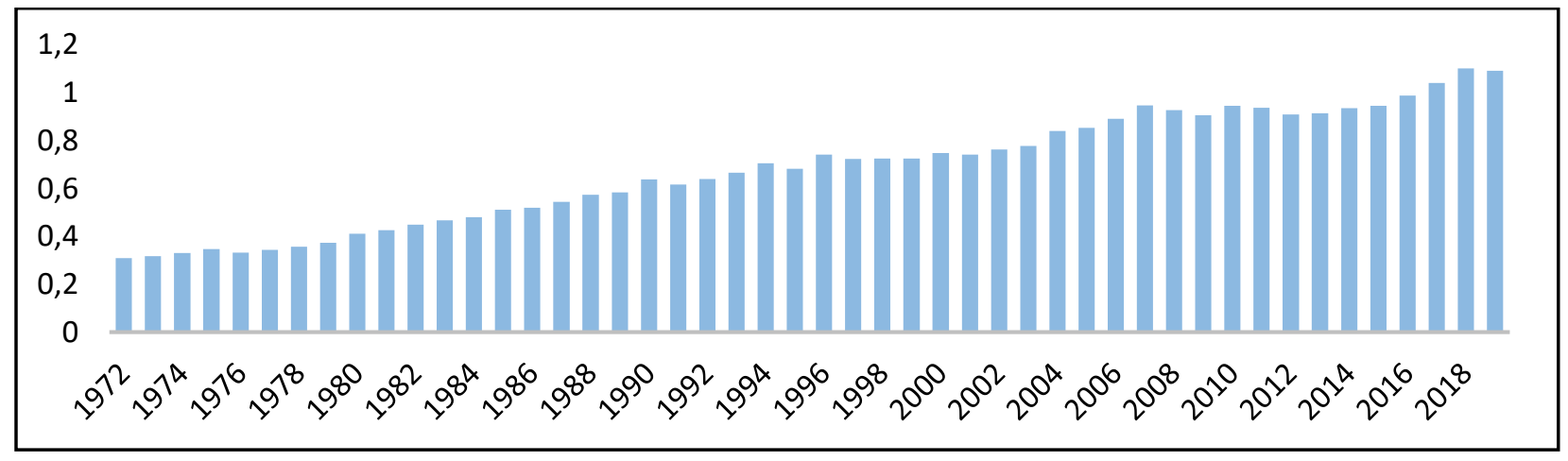


Figure1. $\mathrm{CO}_{2}$ emissions metric ton per capita (Bank, 2017) ('BP Statistical Review of World Energy Statistical Review of World' 2019)

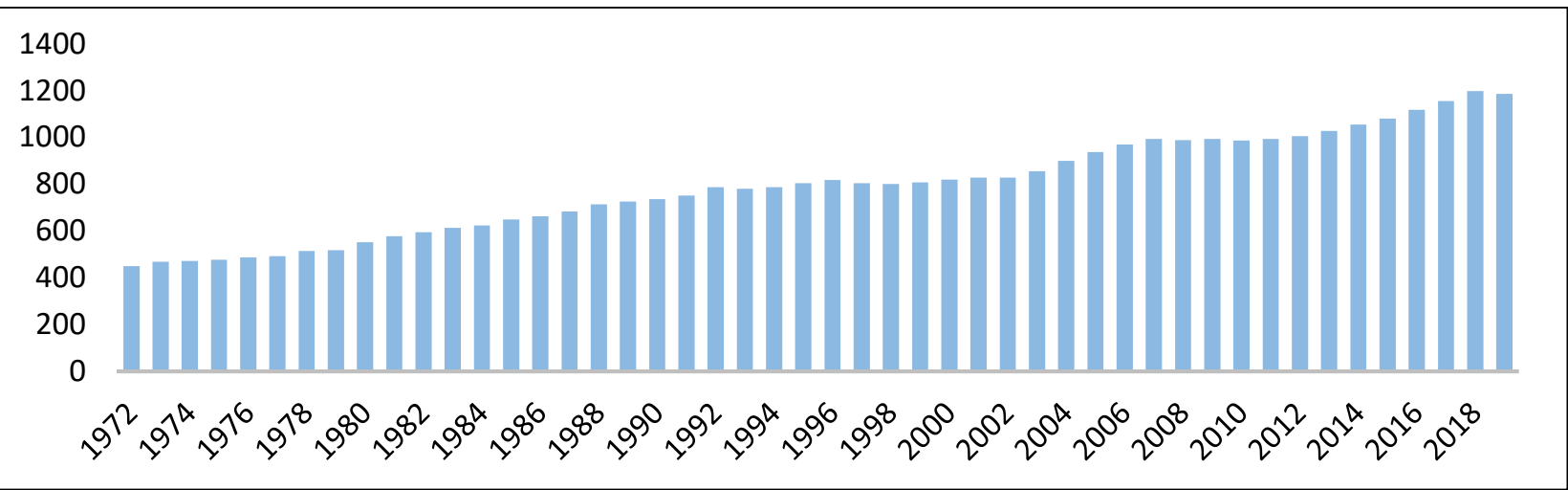

Figure 2. GDP per capita constant in USD (Bank, 2017)

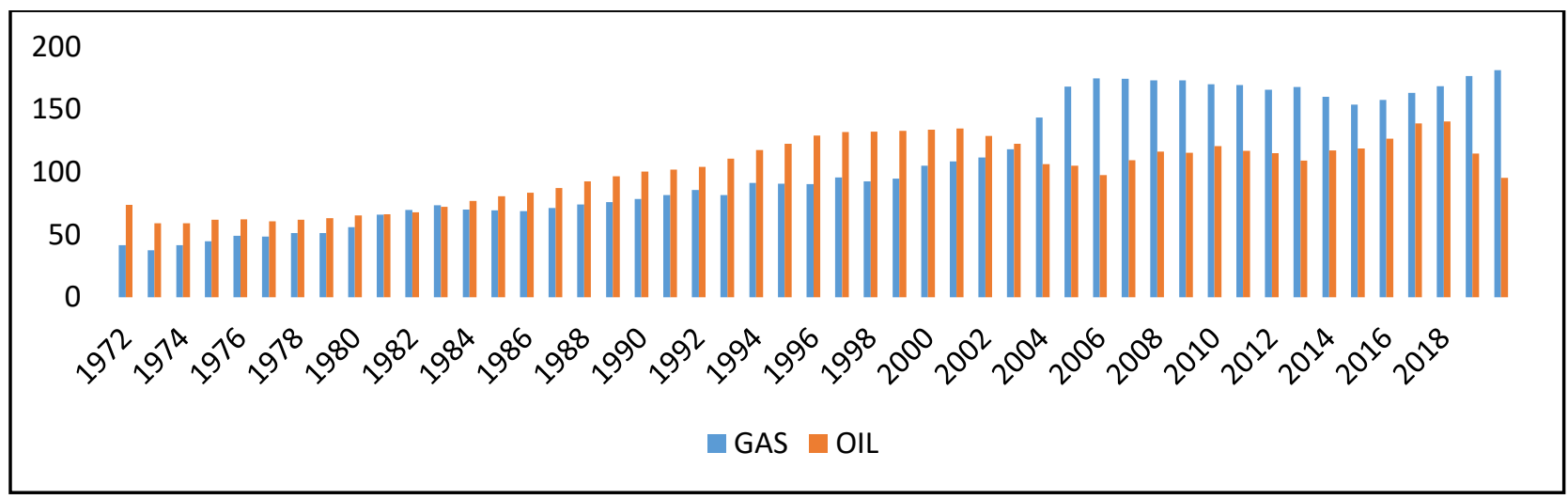

Figure 3. Gas and oil consumptions per capita in tons (BP Statistical Review of World Energy Statistical Review of World, 2019) 


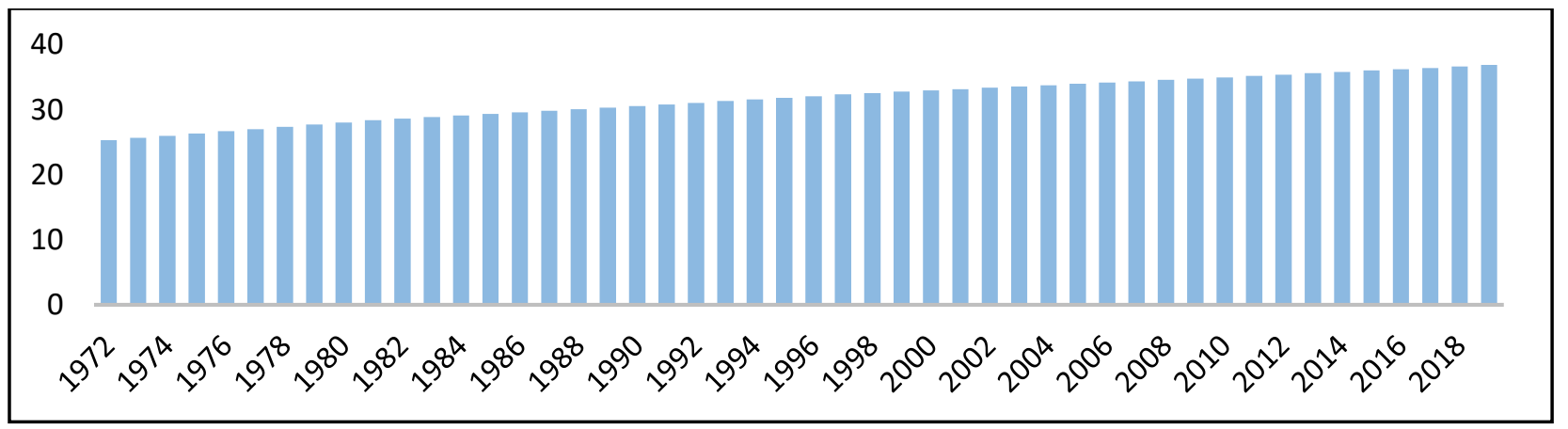

Figure 4. Urbanization (ratio of urban population to the total population) (Bank, 2017)

\section{Literature review}

In the early 1990s, it was realized that environmental degradation was a big concern for people of the planet and the other livelihoods. For this growing concern, it becomes more prominent for researchers to study this area. Since then, the environmental Kuznets curve's idea have got the central position to examine the phenomenon of pollution and sustainable economic growth relationship. Kuznets curve is a non-linear representation of economy and degradation. Besides that, energy use has grown enormously since the late 1950s, and it continues to do so at an increasing rate day by day, as this is apparent from various studies, these include the International panel on climate change (IPCC), World Bank Indicators and British petroleum statistical review. Although this study mainly focuses on EKC in the wake of Pakistan with other parameters including as environmental degradation, per capita energy consumption, manufacturing, financial development, urbanization, and trade openness.

Over the last three decades, there have been numerous empirical researches on EKC with pollution and economic growth. In 1991, two researchers Grossman and Krueger found that at first, per capita income increased with environmental degradation. Second, per capita income 
increment reached the threshold, and rising per capita income started improving the environment (Grossman and Krueger, 1991). Shukla and Parikh, in 1992 (Shukla and Parikh, 1992) found an avoidable positive relationship between the size of an urban area and poor quality of air and also highlighted that this positive relation diminished with economic expansion. However, they concluded that restricting urbanization in developing countries would not achieve environmental goals. Shafik and Bandyopadhyay (Shafik and Bandyopadhyay, 1992) noticed U-shape between environmental indicators and economic growth, and also concluded that income had a significant impact on the environment, and climate indicators started to improve with the middle-income stage.

Ugur Pata, in 2018 (Pata, 2018c) found that EKC existed with the inverted U-shape curve for Turkey, and also calculated the turning point of the economy detected outside of the sample and suggested that export and non-carbohydrate energy was a solution to mitigate the environmental impacts. In another publication, he concluded that only renewable energy could not overcome the impact of carbon emissions (Pata, 2018a). Chen et al. (Chen, Wang and Zhong, 2019) obtained two different outcomes with economic growth, foreign trade, non-renewable and renewable energy production for China. In the non-renewable energy production part, there was no existence of the EKC, on the other hand, with the renewable energy part, there was the existence of the Kuznets curve and finally concluded that renewable energy was a hope to overcome the emissions problem for China. Zhang et al. (Zhang et al., 2019) showed a persistent role of construction and manufacturing industries to degrade the environment, and out of 121 countries in 95, confirmed the EKC hypothesis. Shahbaz et al. (Shahbaz et al., 2020) studied 30 provinces of the Republic of China and found out that the Kuznets curve hypothesis with ushaped prevails in 20 of 30 provincial areas. Ahmed (Ahmed, 2017) in his paper concluded that 
in BRICS countries EKC framework existed in the economy with energy consumption and trade openness. He also mentioned that monetary growth and financial development contributed to energy efficiency after the bottleneck income level. Similarly, Dong et al (Dong, Sun and Hochman, 2017) found a strong relationship of EKC in BRICS countries. Kasman (Kasman and Duman, 2015) noticed the present of the U-shape and EKC hypothesis in EU member countries. On the contrary, Bouluk and Mert (Bölük and Mert, 2014) did not find evidence of the Kuznets curve for 16 chosen EU member states with panel data framework. With panel data of 20 Latin American sovereign countries, Hanif (Hanif, 2017) achieved the U-shaped curve and found that urbanization growth and oil import significantly deteriorated the environment. Bilgili (Bilgili, Koçak and Bulut, 2016) found that the Kuznets curve existed in 17 OECD nations with inverted u- shape and argued that providing easy access for the renewable energy technologies would boost per capita income and eventually contributed to combating the emissions. Similar studies with the EKC hypothesis conducted in different countries considering GDP per capita, trade openness, urbanization, population density, and foreign direct investment, along with several other indicators. EKC studies have been conducted by Pao and Tsai (Pao and Tsai, 2010) for Chinese provinces, Sabori et al. (Saboori, Sulaiman and Mohd, 2012) for Malaysia, Al - Mulali and Oztruk (Al-Mulali and Ozturk, 2016) for EU countries, Ibrahim and law (Ibrahim and Law, 2014) for BRICS, Antonakakis et al. (Antonakakis, Chatziantoniou and Filis, 2017) performed research for middle east countries, and Dogan and Inglesi-Lotz (Dogan and Inglesi-Lotz, 2017) worked for developed and developing nations. Unlike EKC publications, there are some works representing the N-shape curve and no EKC at all (Sinha et al.(Sinha, Shahbaz and Balsalobre, 2018), Terrell (Terrell, 2020), Alexsandra, et al. (Allard et al., 2018)) 
Most of the researchers did their work with individual blocks of countries with the panel or cross-sectional data framework linking income achievements with pollution (Dinda, 2004) (Hill, Magnani and Hill, 1955) (David I, Michael and Edward, 1996). Recently there has been efforts to see the single country relationship with per capita income and environmental pollution using time series data because the individual country does not have the same polluting patterns as panel data analysis with the block-level framework (Friedl and Getzner, 2003) (Lindmark, 2002) (Stern, Common and Barbier, 1996). Ahmed et al.(Ahmad et al., 2017) showed the reversed Ushaped curve for Croatia, Pata, Akbostanci, for Turkey (Pata, 2018c)(Pata, 2018a)(Akbostanci, Türüt-Aşik and Tunç, 2009), Fodha et al. for Tunisia (Fodha and Zaghdoud, 2010) for Tunisia, Moutinho for Spain and Portugal (Moutinho, Varum and Madaleno, 2017) and Jayanthakumaran et al. for India and China (Jayanthakumaran, Verma and Liu, 2012).

However, for EKC U- shape relationship, the point where the economy plays a vital role to curtail environmental pollution happens when the turning point achieves within the sample size. Many studies have highlighted that per capita income was not playing a meaningful role in mitigating the carbon emissions when learning that the critical point was beyond the size of sample Pata (Pata, 2018a)(Pata, 2018c), Dinda (Dinda, 2004) and Sugiawan and Managi (Sugiawan and Managi, 2016)). Zhang et al.(Zhang et al., 2019) studied 121 countries out of which 11 countries reached the first level turning point, 21 countries achieved the second level turning point, 50 countries prevailed the third level turning point of the economic progress, and 13 countries did not reach any level of the turning point.

This study focuses on Pakistan with the EKC framework considering $\mathrm{CO}_{2}$ emissions, per capita GDP (Constant 2010), urbanization, financial development, manufacturing, trade openness, and per capita energy consumption as oil and gas. According to the environmental performance index 
(EPI) (Morse and Morse, 2019) report, Pakistan ranks 142 out of the 180 countries on the index card, showing concerns for the country being low level per capita income. A study performed by Rafique and Rehman (Rafique and Rehman, 2017) showed that in 2050, carbon dioxide emissions of Pakistan would become three times, which is alarming with the current scenario of climatic conditions. Under the agreement of the Kyoto protocol on climate change, Pakistan government has focused on mitigating pollution while accelerating the economy and ensuring energy efficiency. Kanwal et al. (Mirza and Kanwal, 2017)) and Danish et al (Danish et al., 2017) found strong evidence of an inverted U -shape curve for Pakistan and concluded that overall carbohydrate energy consumption was solely responsible for $\mathrm{CO} 2$ emissions. Gokmenoglu et al. (Gokmenoglu and Taspinar, 2018) with agriculture-induced EKC-based results confirmed the hypothesis for Pakistan. Shahbaz et al. (Shahbaz, Lean and Shabbir, 2012) verified the EKC curve in Pakistan. Malik et al. (Malik et al., 2020) validated the Kuznets curve in Pakistan with symmetric and asymmetric approaches. Nasir and Rehman (Nasir and Ur Rehman, 2011) also proved the idea of EKC with selected variables. Nasreen et al. (Nasreen, Anwar and Ozturk, 2017) in their study of the Southeast Asian region countries, in the framework of the EKC, authenticated the Kuznets curve for Pakistan.

For Pakistan, some studies employed the time series model to explore the hypothesis of EKC. Danish et al. (Danish et al., 2017) applied the ARDL bounds testing approach with the VAR model using the sample period of 1970 - 2012 for per capita GDP, per capita renewable and nonrenewable energies. He concluded that the EKC was present in the long- and short-run and suggested that renewable energy could play a vital role in overcoming emissions' effects. Gokmenglu et al. (Gokmenoglu and Taspinar, 2018) used the ARDL bounds test model with Johansen co-integration test for exploring the association among the variables, taking sample 
period of 1971 and 2014 for per capita income, per capita kg oil equivalent of energy consumption, value-added GDP of the agricultural sector, and thousand tons of carbon emission. They concluded with outcomes that the EKC did exist and also suggested similar studies could employ other developing nations resembling the same economic model as Pakistan. Shahbaz et al. (Shahbaz, Lean and Shabbir, 2012) adopted the ARDL bounds test for co-integration with UECM approach and Granger causality for assessing the relationship between $\mathrm{CO}_{2}$ emissions, income progress, and energy consumption from 1971 to 2009. Results supported the EKC hypothesis over the long period and found a one-way association between economic expansions to $\mathrm{CO} 2$ emissions. Malik et al. (Malik et al., 2020) applied the ARDL and NARDL methods to check the association among per capita $\mathrm{CO}_{2}$ emissions, per capita income, oil price, foreign direct investment, and other control variables. Results of their study confirmed the EKC hypothesis with the symmetric and non-symmetric model, carbon pricing could apply to mitigate the emissions and with renewable energy mix for commercial and household could overcome the issue of degradation of the environment. Nasir and Rehman (Nasir and Ur Rehman, 2011) used Johnsen co-integration with the VECM approach for the sample period between 1972 to 2008, and concluded the EKC curve did exist only over the long time, but not in the short span, and casual relationship was one-way from income to consumption. Nasreen et al (Nasreen, Anwar and Ozturk, 2017) examined time-series data of 1980 -2012 utilizing bounds testing for cointegration and Granger causality methods for assessing an association among indicators as $\mathrm{CO}_{2}$ emissions, financial index, per capita income, energy consumption, and population density. In her outcomes, she validated the EKC of Pakistan. Moreover, she found the casualty impact from the financial index to carbon emissions.

\section{Data, models \& methods}




\subsection{Data}

This study validates EKC for Pakistan for duration of 48 years, from 1972 to 2019. The data for selected parameters such as carbon emissions, GDP, urbanization, financial development, manufacturing, trade openness, oil consumption, and gas consumption were taken from British Petroleum ('BP Statistical Review of World Energy Statistical Review of World', 2019) statistical review and other above-mentioned variables data were collected from World Bank Indicators (WDI)(Bank, 2017).

\subsection{Model}

To study the association between environmental degradation and economic growth, we used an autoregressive distributed lag (ARDL) based log-linear quadratic time series model to analyze the parameters.

$\ln \mathrm{C}_{\mathrm{t}}=\mu_{0}+\mu_{1} \ln X_{t}+\mu_{2}\left(\ln \mathrm{X}_{\mathrm{t}}\right)^{2}+\mu_{3} \ln U_{t}+\mu_{4} \ln F D_{t}+\mu_{5} \ln M F_{t}+\mu_{6} \ln O_{t}+\mu_{7} \ln G_{t}+\mu_{8} \ln T_{t}+\in_{t}$

where $\mathrm{C}$ is the carbon emissions (metric tons per capita), $\mathrm{X}$ is the GDP per capita constant in $\mathrm{USD}, \mathrm{U}$ is the urbanization (ratio of urban population to the total population), FD is the financial development (domestic credit to the percentage of the GDP), MF is the manufacturing valueadded percentage of GDP, $\mathrm{O}$ is the oil consumption (per capita $\mathrm{kg}$ of oil equivalent), $\mathrm{G}$ is the gas consumption (per capita $\mathrm{kg}$ of oil equivalent) and $\mathrm{T}$ is the import and export of goods and services percentage of GDP 
In the time series ARDL model equation, the hypothesis of the EKC is acceptable when $\mu 1>0$ and $\mu 2<0$. When $\mu 1>0$, Carbon emissions simultaneously grow with the increase in per capita GDP, and after reaching the peak, emissions start is decreasing with an increase in per capita income and $\mu 2$ becomes less than 0 .

$X^{*}=-\mu 1 / 2 \mu 2$

The point where environmental retardation occurs is $X^{*}$ and $\exp \left(X^{*}\right)$ represents the monetary value of the position and, the coefficients of the energy consumptions, urbanization, and manufacturing are expected to be larger than 0 , and the remaining coefficients of the other parameters, depend on the economic growth.

\subsection{Methods}

\subsubsection{Stationary properties (Unit Root Test)}

Before running the data in a time series mode 1 , it is necessary to validate the data, to see whether the data is stationary or not; otherwise, results will not be satisfactory. For checking the unit root properties of data, there are many models at the disposal, such as Dickey-Fuller(DF) (Dickey and Fuller, 1981), Augmented Dickey-Fuller(ADF), Phillips-Perron(PP), Kwiatkowski, Phillips, Schmidt, and Shin(KPSS)(Kim and Schmidt, 1990). Here we have used ADF and PP unit root tests. The ADF unit root test includes the lag order to give robust results and avoid autocorrelation issues, and the PP unit root test carries the fittings to circumvent the same problem. 
In the ADF and PP unit root tests, the null hypothesis rejects to accept alternative hypotheses.

For this purpose, the following equations were used:

$\Delta x_{t}=\alpha+\beta_{t}+\Phi x_{t-1}+\sum_{i=1}^{n} v_{i} \Delta x_{t-1}+\varrho_{t}$

$\Delta x_{t}=\alpha+\beta_{t}+\Phi x_{t-1}+\varrho_{t}$

Before constructing the model, a unit root test is performed on the data parameters to check the stability. Therefore, to confirm the accuracy, we employ Augmented Dickey-Fuller(ADF) and Philps Perron (PP) unit root tests. For ADF and PP tests, the null hypothesis implies that data have a unit root and, the alternate hypothesis claims that data is stationary.

\subsubsection{ARDL (Bounds Testing Approach)}

Pesaran and Shin (1995) (Pesaran, Shin and Smith, 2001) developed the ARDL bounds testing approach to study the co-integration relationship of parameters In this method, there is no restriction on parameters to be integrated of first-order or zero-order or a combination of both. There are many reasons to apt ARDL approach over the other. Such as, it is free from problems associated with the order of integration. The analysis of impacts for independent and dependent parameters of long-run and short-run at the same time. Also, the ARDL method has more suitable properties as well as more consistent results for small samples. Here in this research, short-run and long-run coefficients are examining together. Following Eq. shows the Unrestricted error correction model(UECM).

$$
\begin{aligned}
& \Delta \ln C_{t}=\alpha_{0}+\sum_{i=1}^{j} \alpha_{1 i} \Delta \ln C_{t-i}+\sum_{i=0}^{k} \alpha_{2 i} \Delta \ln X_{t-i}+\sum_{i=0}^{l} \alpha_{3 i} \Delta \ln \left(X_{t-i}\right)^{2}+\sum_{i=0}^{m} \alpha_{4 i} \Delta \ln U_{t-i}+ \\
& \sum_{i=0}^{n} \alpha_{5 i} \Delta \ln F D_{t-i}+\sum_{i=0}^{o} \alpha_{6 i} \Delta \ln M F_{t-i}+\sum_{i=0}^{p} \alpha_{7 i} \Delta \ln O_{t-i}+\sum_{i=0}^{q} \alpha_{8 i} \Delta \ln G_{t-i}+\sum_{i=0}^{r} \alpha_{9 i} \Delta \ln T_{t-i}+ \\
& \delta_{0} \ln C_{t-1}+\delta_{1} \ln X_{t-1}+\delta_{2} \ln \left(X_{t-1}\right)^{2}+\delta_{3} \ln U_{t-1}+\delta_{4} \ln F D_{t-1}+\delta_{5} \ln M F_{t-1}+\delta_{6} \ln O_{t-1}+ \\
& \delta_{7} \ln G_{t-1}+\delta_{8} \ln T_{t-1}+\epsilon_{t}
\end{aligned}
$$


In equation, $\alpha 0$ is the constant term, $\Delta$ is the difference operator, $\mathrm{et}$ is the white - noise error, $\alpha 1$, $2,3,4,5,6,7,8,9$ are the short- run coefficients, $\delta 0,1,2,3,4,5,6,7,8$ are long - run coefficients, $\mathrm{j}, \mathrm{k}$, 1, m, n, o, p, q and $\mathrm{r}$ are the optimal lag length based on Akaike information criteria (AIC) and Schwarz-Bayesian criteria (SBC).

These models allow the separate lag lengths for each of the parameters used in the research.

For case III (Unrestricted intercept and no trend) model, the null hypothesis $(\mathrm{H} 0: \alpha 0=\delta 0=\delta 1=$ $\delta 2=\delta 3=\delta 4=\delta 5=\delta 6=\delta 7=\delta 8=\delta 9)$ considering no co-integration among the parameters examined against the alternative hypothesis (H_alternative: $\alpha 0 \neq \delta 0 \neq \delta 1 \neq \delta 2 \neq \delta 3 \neq \delta 4 \neq \delta 5 \neq$ $\delta 6 \neq \delta 7 \neq \delta 8 \neq \delta 9$ ) respectively. By the case (III), the F- statistics value achieves, compared with the tabulated critical value given by Pesaran and Shin (Pesaran, Shin and Smith, 2001) confirmed the co-integration among the parameters. There are two critical value tables, one is by Pesaran and Shin (Pesaran, Shin and Smith, 2001) and the other one by Narayan (Narayan, 2005). The table achieved by Pesaran et al. (2001) is considering for samples ranging from 500 to 1000 observations, but on the other hand, the table created by Narayan is suitable for sample ranging 30 to 80 .

In comparison with other traditional co-integration tests, the ARDL framework complies better with smaller sizes of sample and produces improved results. There are three conditions regarding the co-integration test. The conducted F- stat value is greater than the tabulated critical value, then one may say that it is co-integration among the variables. The second F-stats calculated value is lower than the tabulated critical value, and then there is no co-integration among the parameters. And the third is that when the value falls between the upper and lower bounds, then the co-integrating results are not conclusive. These all F-stats results are compared with the help 
of null and alternative hypotheses. As the co-integration establishment was confirmed among parameters with the bounds test and long-term parameters coefficients achieved, short-term parameters coefficients establishment was confirmed by error correction model (ECM) based on the ARDL framework.

$\Delta \ln C_{t}=\lambda_{0}+\sum_{i=1}^{a} \lambda_{1 \dot{ }} \Delta \ln C_{t-i}+\sum_{i=0}^{b} \lambda_{2 i} \Delta \ln X_{t-i}+\sum_{i=0}^{c} \lambda_{3 i} \Delta \ln \left(X_{t-i}\right)^{2}+\sum_{i=0}^{d} \chi_{4 i} \Delta \ln U_{t-i}+$ $\sum_{i=0}^{e} \lambda_{5 i} \Delta \ln F D_{t-i}+\sum_{i=0}^{i} \lambda_{6 i} \Delta \ln M F_{t-i}+\sum_{i=0}^{g} \lambda_{7 i} \Delta \ln O_{t-i}+\sum_{i=0}^{h} \lambda_{8 i} \Delta \ln G_{t-i}+$ $\sum_{i=0}^{i=0} \lambda_{9 i} \Delta \ln T_{t-i}+\gamma E C \bar{T}_{t-1}+\epsilon_{t}$

where $\chi 0$ is the constant term, $\chi 1,2,3,4,5,6,7,8,9$ are the short-run coefficients, $\gamma$ is the long-run coefficients with error correction term (ECT), and a, b, c, d, e, f, g, h and j are the optimal lag length based on Schwarz Bayesian criterion (SBC)

The ECT represents that how much time is needed for short-run parameters to compensate for the long-run parameters. For ECT based model, the time term should be negative and statistically significant. Finally, to ensure stability for the ARDL framework, diagnostic tests such as Serial Correlation, Ramsey Reset, Normality, Heteroscedasticity, Cumulative Sum (CUSUM), and Cumulative Sum of Squares (CUSUMSQ).

\section{Results and Discussion}

This research examines the multivariate relationship of economic progress and environmental degradation with the selected parameters; initially, at the first step, the unit root properties of selected parameters were checked using ADF and PP unit root tests. The maximum slack is calculated by the formula $\left(\mathrm{K}_{\max }=\operatorname{int}\left\{12 *(\mathrm{~T} / 100)^{\wedge} 0.25\right\}\right)$ given by (Schwert, 2002). And for the ADF and PP unit root tests, the slack length chose with SBC based standards. Table 1 represents the unit root test results. All the parameters are stationary at $\mathrm{I}(1)$ or first difference whereas, urbanization is stationary at $\mathrm{I}(0)$ or level, but none of the parameters are stationary at $\mathrm{I}(2)$. 
Therefore, to check the establishment of long-term association among the parameters, we applied the ARDL bounds testing technique.

Table 1. Unit root test results (PP\& ADF)

\begin{tabular}{|c|c|c|c|c|c|c|c|c|c|c|c|c|}
\hline & $\begin{array}{c}\text { With } \\
\text { Constant }\end{array}$ & & & $\begin{array}{c}\text { With } \\
\text { Constant }\end{array}$ & & & $\begin{array}{c}\text { With } \\
\text { Constant }\end{array}$ & & & $\begin{array}{c}\text { With } \\
\text { Constant }\end{array}$ & & \\
\hline & t-Statistic & Prob. & & t-Statistic & Prob. & & t-Statistic & Prob. & & t-Statistic & Prob. & \\
\hline $\ln C$ & -0.044 & 0.95 & No & -6.407 & 0 & $* * *$ & 0.093 & 0.962 & No & -6.38 & 0 & $* * *$ \\
\hline $\ln X$ & -1.396 & 0.578 & No & -6.328 & 0 & $* * *$ & -1.486 & 0.533 & No & -6.321 & 0 & $* * *$ \\
\hline $\ln X 2$ & -1.034 & 0.735 & No & -6.22 & 0 & $* * *$ & -1.098 & 0.71 & No & -6.213 & 0 & $* * *$ \\
\hline $\ln U$ & -7.428 & 0 & $* * *$ & -1.095 & 0.71 & No & -2.669 & 0.086 & $*$ & -1.308 & 0.62 & No \\
\hline $\operatorname{lnFD}$ & -1.915 & 0.323 & No & -6.29 & 0 & $* * *$ & -1.723 & 0.414 & No & -6.327 & 0 & $* * *$ \\
\hline $\operatorname{lnMF}$ & -2.440 & 0.136 & No & -7.606 & 0 & $* * *$ & -2.292 & 0.178 & No & -7.606 & 0 & $* * *$ \\
\hline $\ln \mathrm{O}$ & -1.105 & 0.708 & No & -3.867 & 0 & $* * *$ & -1.308 & 0.619 & No & -3.867 & 0 & $* * *$ \\
\hline $\ln G$ & -2.248 & 0.193 & No & -4.997 & 0 & $* * *$ & -2.548 & 0.11 & No & -5.141 & 0 & $* * *$ \\
\hline \multirow[t]{3}{*}{$\ln \mathrm{T}$} & -2.156 & 0.224 & No & -8.451 & 0 & $* * *$ & -2.156 & 0.225 & No & -8.098 & 0 & $* * *$ \\
\hline & $\begin{array}{c}\text { With } \\
\text { Constant } \\
\text { \& Trend }\end{array}$ & & & $\begin{array}{c}\text { With } \\
\text { Constant } \\
\text { \& Trend }\end{array}$ & & & $\begin{array}{c}\text { With } \\
\text { Constant } \\
\text { \& Trend }\end{array}$ & & & $\begin{array}{c}\text { With } \\
\text { Constant } \\
\text { \& Trend }\end{array}$ & & \\
\hline & t-Statistic & Prob. & & t-Statistic & Prob. & & $\mathrm{t}$-Statistic & Prob. & & t-Statistic & Prob. & \\
\hline $\ln C$ & -2.321 & 0.416 & No & -6.379 & 0 & $* * *$ & -2.188 & 0.487 & No & -6.353 & 0 & $* * *$ \\
\hline $\ln X$ & -1.979 & 0.599 & No & -6.416 & 0 & $* * *$ & -1.812 & 0.685 & No & -6.409 & 0 & $* * *$ \\
\hline $\ln X 2$ & -2.095 & 0.537 & No & -6.228 & 0 & $* * *$ & -2.05 & 0.561 & No & -6.22 & 0 & $* * *$ \\
\hline $\ln U$ & -1.180 & 0.905 & No & -1.904 & 0.64 & No & -2.318 & 0.417 & No & -2.396 & 0.38 & No \\
\hline $\operatorname{lnFD}$ & -2.696 & 0.243 & No & -6.225 & 0 & $* * *$ & -2.5 & 0.327 & No & -6.269 & 0 & $* * *$ \\
\hline $\operatorname{lnMF}$ & -2.865 & 0.182 & No & -7.546 & 0 & $* * *$ & -2.783 & 0.21 & No & -7.546 & 0 & $* * *$ \\
\hline $\ln \mathrm{O}$ & -1.079 & 0.923 & No & -3.926 & 0.02 & $* *$ & -1.325 & 0.871 & No & -3.926 & 0.02 & $* *$ \\
\hline $\ln G$ & -1.920 & 0.631 & No & -5.197 & 0 & $* * *$ & -2.354 & 0.399 & No & -5.396 & 0 & $* * *$ \\
\hline $\ln \mathrm{T}$ & -2.209 & 0.475 & No & -9.498 & 0 & $* * *$ & -2.21 & 0.475 & No & -8.126 & 0 & $* * *$ \\
\hline
\end{tabular}

Note:

a: (*) Significant at the 10\%; (**) Significant at the 5\%; (***) Significant at the $1 \%$ and (no) Not Significant b: Lag Length based on SBC

The ARDL bounds testing technique was used to examine the co-integration connection between the variables included in the research. The best lag durations for bounds testing were determined using the AIC, SBC, and HQ information criteria. The AIC assists in the selection of the highest feasible lag length, whereas the SBC aids in the shortest possible lag length. Figure 5 displays 
the results of the ARDL $(2,2,2,0,0,3,1,2,3)$ model's study of SBC information criterion minimization.

\section{Schwarz Criteria (top 20 models)}

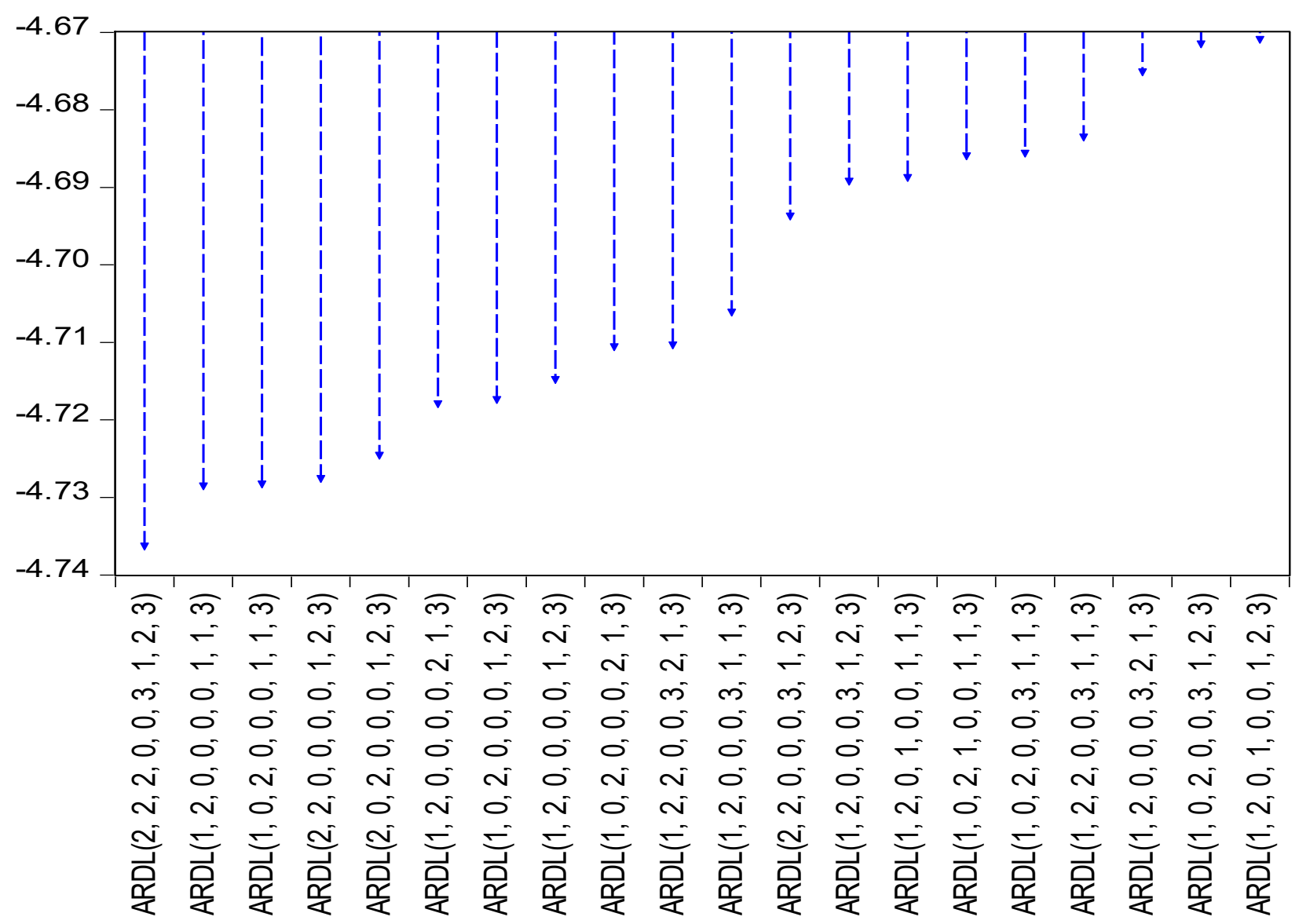

Figure 5, Model selection summary

Table 2 represents the confirmation of the co-integration relationship for Case-II and Case-III by rejecting the null and accepting the alternative hypothesis. The generated F-statistics value with a $1 \%$ significant level was achieved using the ARDL model and, the value of the f- statistics was compared with two different critical value tables. One critical value table of the (Pesaran, Shin, and Smith, 2001) another by (Narayan 2005), and the results of the f-statistics confirmed the existence of the co-integration. 
Table 2. Bound test results of the model for the long run.

Null Hypothesis: The non- existence of co-integration among the variables.

Alternative Hypothesis: The existence of co-integration among the variables

\begin{tabular}{|c|c|c|c|c|}
\hline $\mathbf{k}=\mathbf{8}$ & \multicolumn{2}{|c|}{ CASE -II } & \multicolumn{2}{c|}{ CASE -III } \\
\hline F-statistic & \multicolumn{2}{|c|}{$27.39583^{* *}$} & & $\mathrm{I}(0)$ \\
\hline $\begin{array}{c}\text { Pesaran et.al Critical Table } \\
\text { Value }\end{array}$ & $\mathrm{I}(0)$ & $\mathrm{I}(1)$ & 1.88 & $\mathrm{I}(1)$ \\
\hline $10 \%$ & 1.8 & 2.8 & 2.14 & 2.99 \\
\hline $5 \%$ & 2.04 & 2.08 & 2.65 & 3.3 \\
\hline $1 \%$ & 2.5 & 3.68 & $\mathrm{I}(0)$ & 3.97 \\
\hline Narayan Critical Table value & $\mathrm{I}(0)$ & $\mathrm{I}(1)$ & 2.205 & $\mathrm{I}(1)$ \\
\hline $10 \%$ & 2.099 & 3.181 & 2.593 & 3.421 \\
\hline $5 \%$ & 2.457 & 3.65 & 3.498 & 3.941 \\
\hline $1 \%$ & 3.282 & 4.73 & 5.149 \\
\hline
\end{tabular}

Note: Asterisk (*) sign represents the significance level

In Table 3, all the long-term coefficients show the significance and validating the relationship with $\mathrm{CO} 2$ emissions $(\operatorname{lnC}) . \mathrm{GDP}(\ln \mathrm{X})$, financial development $(\operatorname{lnFD})$, urbanization $(\ln U)$, manufacturing $(\ln M F)$, oil consumption $(\operatorname{lnO})$, and gas consumption (lnG) having a positive relationship with emissions showing that they cause a hike in $\mathrm{CO} 2$ emissions and contrary to that trade openness $(\ln \mathrm{T})$ representing negative association with $\mathrm{CO} 2$ emissions in long-term. The coefficients of GDP and its square were found to be 4.277 and -0.270 , respectively, showing that $\mu 1>0$ and $\mu 2<0$. The result affirms an establishment of the EKC for the long term for Pakistan. The critical point of the monetary value becomes $2735.19 \$$, which is way more than the sample values of per capita GDP.

Table 3. Long-run estimates of the model with ARDL bounds

\begin{tabular}{|c|c|c|}
\hline Variable & Coefficient & t-Statistic \\
\hline $\ln \mathrm{X}$ & 4.277 & 7.079 \\
\hline $\ln \mathrm{X} 2$ & -0.270 & -5.808 \\
\hline $\ln \mathrm{C}$ & 0.649 & 2.436 \\
\hline $\operatorname{lnFD}$ & 0.079 & 3.986 \\
\hline $\operatorname{lnMF}$ & 0.171 & 3.615 \\
\hline $\ln \mathrm{O}$ & 0.194 & 8.336 \\
\hline $\ln \mathrm{O}$ & 0.130 & 3.316 \\
\hline
\end{tabular}




\begin{tabular}{|c|c|c|}
$\ln \mathrm{T}$ & -0.087 & -3.196 \\
\hline $\mathrm{C}$ & -36.511 & -17.953 \\
\hline
\end{tabular}

The ARDL model was also checked for the proper functioning and functional form with different diagnostic tests shown in Table 4. For the autocorrelation issue, the Breusch-Godfrey test (BGLM) was employed in the model, and it confirmed that there was no issue of serial correlation in the model. Breusch-Pagan-Godfrey (BPG) and ARCH tests confirmed that there was no issue of heteroscedasticity to the model. The Jarque-Bera and Ramsey- Reset tests also showed that the error term was normally distributed, and the model had proper functional form.

Table 4. Relationship level of the time series model

\begin{tabular}{|c|c|c|}
\hline Diagnostics & F-statistic & P-value \\
\hline BG-LM(Serial correlation) & 2.429 & 0.111 \\
\hline Jarque- Bera & 4.320 & 0.115 \\
\hline BPG & 0.762 & 0.741 \\
\hline ARCH & 0.018 & 0.893 \\
\hline Ramsey Reset & 0.139 & 0.891 \\
\hline
\end{tabular}

Table 5 representing short-term coefficients and coefficient of the ECM based on the ARDL model. In the short-run model, the error correction component has a coefficient of -1.70 , implying that instead of monotonically converging to the equilibrium route, the error correction process swings about the long-run value in a damping way. Once this process is complete, however, convergence to the equilibrium route occurs quickly. ECM term is in parallel to the (Narayan and Smyth, 2006).

Table 5. Error correction table for selected ARDL model

\begin{tabular}{|c|c|c|}
\hline Variable & Coefficient & t-Statistic \\
\hline $\mathrm{D}(\ln C(-1))$ & 0.188 & 3.484 \\
\hline $\mathrm{D}(\ln X)$ & -0.539 & -0.278 \\
\hline $\mathrm{D}(\ln X(-1))$ & -8.944 & -4.717 \\
\hline $\mathrm{D}(\ln X 2)$ & 0.065 & 0.445 \\
\hline $\mathrm{D}(\ln \mathrm{X}(-1))$ & 0.623 & 4.298 \\
\hline $\mathrm{D}(\operatorname{lnMF})$ & 0.016 & 0.576 \\
\hline $\mathrm{D}(\operatorname{lnMF}(-1))$ & -0.274 & -9.206 \\
\hline $\mathrm{D}(\operatorname{lnMF}(-2))$ & -0.188 & -6.677 \\
\hline \multicolumn{2}{|c}{} \\
\hline
\end{tabular}




\begin{tabular}{|c|c|c|}
$\mathrm{D}(\ln \mathrm{l})$ & 0.092 & 2.685 \\
\hline $\mathrm{D}(\operatorname{lnO})$ & -0.092 & -2.643 \\
\hline $\mathrm{D}(\operatorname{lnO}(-1))$ & -0.132 & -3.306 \\
\hline $\mathrm{D}(\ln \mathrm{T})$ & -0.014 & -0.733 \\
\hline $\mathrm{D}(\ln \mathrm{T}(-1))$ & 0.214 & 11.617 \\
\hline $\mathrm{D}(\operatorname{lnT}(-2))$ & 0.134 & 7.867 \\
\hline $\mathrm{ECM} / \mathrm{CointEq}(-1)^{*}$ & -1.70 & -17.943 \\
\hline
\end{tabular}

$\mathrm{ECM}=\mathrm{LNC}-(4.2772 * \mathrm{X}-0.2702 * \mathrm{X} 2+0.6488 * \mathrm{U}+0.0787 * \mathrm{FD}+0.1714 * \mathrm{MF}+0.1935 * \mathrm{LNG}+0.1304 * \mathrm{LNO}-$ $0.0873 * \mathrm{~T})$

The parameters stability was checked using cumulative sum (CUSUM) of recursive residuals and the cumulative sum of square (CUSUMSQ) tests. The CUSUM test represents systematic changes in regressions coefficients, whereas the CUSUMSQ test finds abrupt or sharp changes in regression coefficients. Figures 6 and 7 of CUSUM and CUSUMSQ tests of the model stability conforming that model is stable as the CUSUM and CUSUMSQ line is between the $5 \%$ upper and lower critical bound.

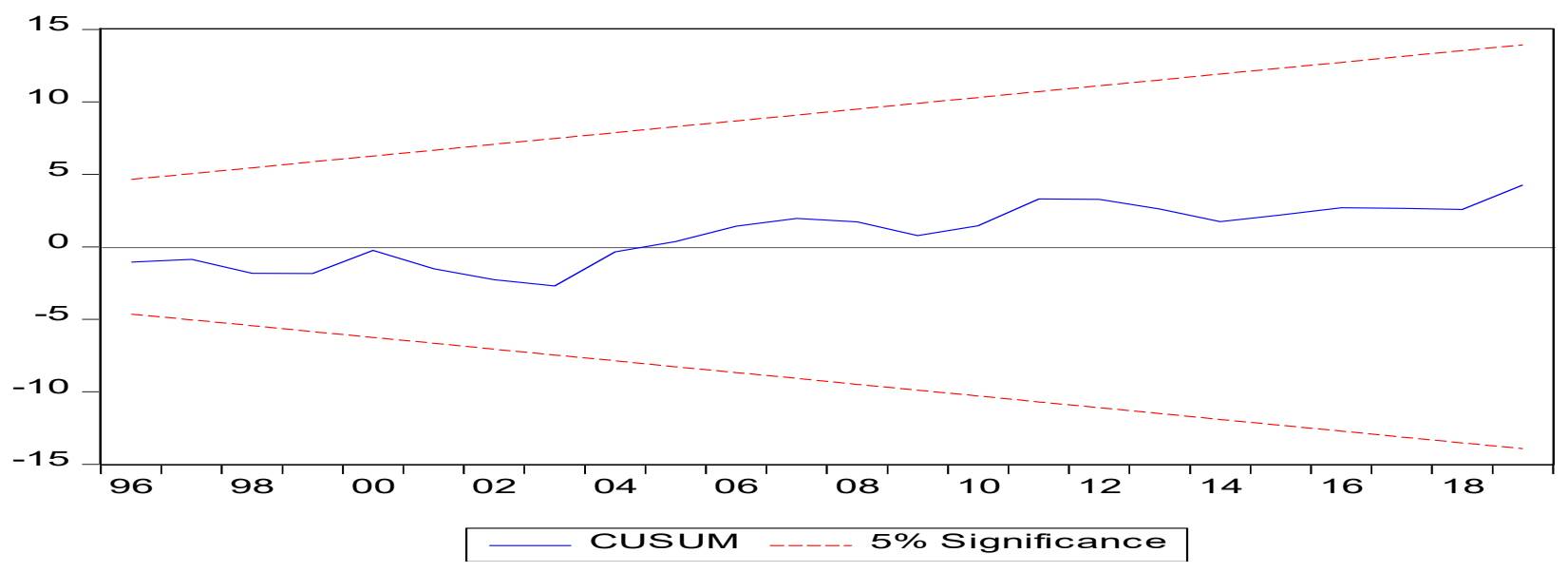

Figure 6. CUSUM test for model stability 


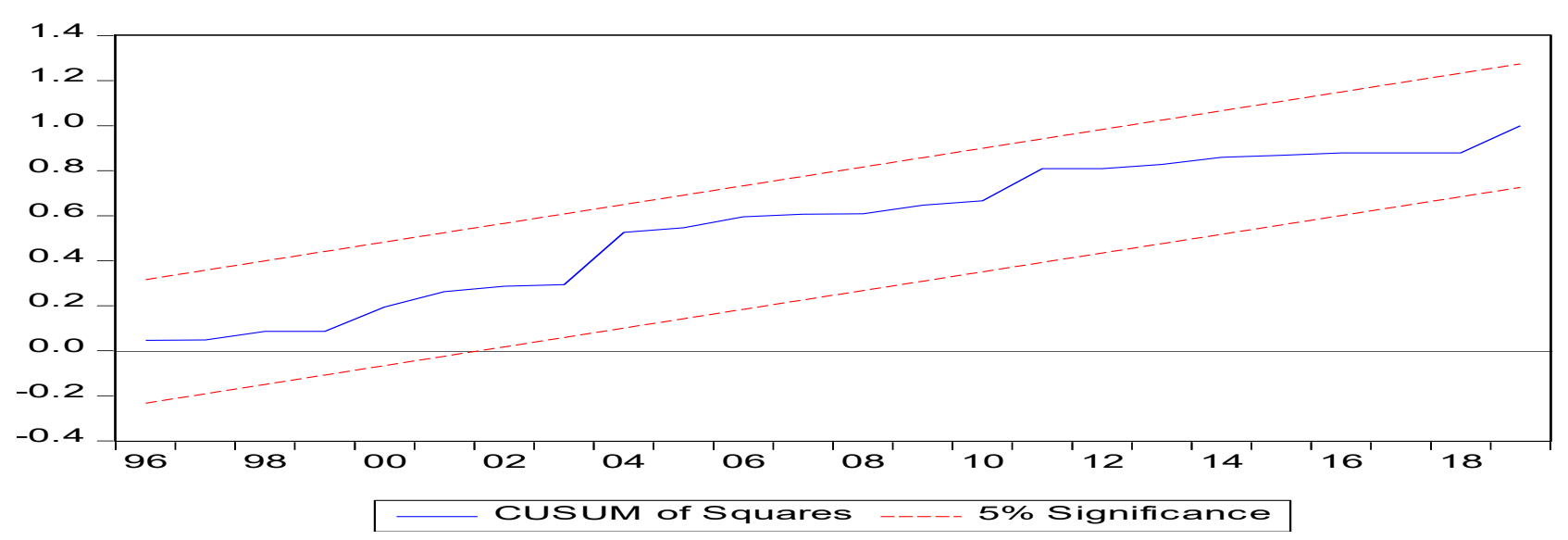

Figure 7. CUSUMSQ test for model stability

\section{Conclusion and Policy Recommendations}

The current study analyzed the establishment of the EKC hypothesis for Pakistan during a period between 1972 and 2019, where ARDL bounds testing approach was applied. The reason for using the ARDL approach due to urbanization was I(0) level stationery and, all the other selected parameters were first order I (1) stationary. We modeled the influences of GDP per capita and its square with other salient parameters including urbanization, financial development, manufacturing, trade openness, and per capita conventional energies as oil and gas.

The results of the selected pool of the parameters for the long run with GDP and its square showing that (i) $1 \%$ increase in economic growth and financial development would increase $\mathrm{CO}_{2}$ emissions in the country by $4.277 \%$ and $0.0787 \%$, respectively. (ii) $1 \%$ increase in Urbanization and manufacturing would increase $\mathrm{CO}_{2}$ emissions by $0.648 \%$ and $0.171 \%$, respectively. (iii) $1 \%$ increase in Oil and gas energy consumption would also increase $\mathrm{CO}_{2}$ emissions by $0.130 \%$ and $0.1935 \%$, respectively. On the other hand, trade openness decreases emissions by $-0.087 \%$ in the long run. In the short run, (i) there was no establishment of the EKC hypothesis with regards to 
the scenario of Pakistan within the selected duration (ii) manufacturing showing negative impact on $\mathrm{CO} 2$ emissions (iii) use of gas showing the positive relationship and contrary to that use of oil shows negative relationship (iv) trade openness indicating an increase in carbon emissions. Therefore, short-term policy changes will not best fit for balance of environmental and economic growth for a country like Pakistan.

Observed results underlined a validation of the EKC hypothesis for a long period, but not for a short period. These outcomes are in line with the other similar studies, Pata (Pata, 2018c)(Pata, 2018a), who analytically confirmed EKC for Turkey and Nutnaree Maneejuk et al (Maneejuk et al., 2020) for 44 different countries.

Moreover, thresh hold point for capita income in the long run was calculated as 2735.191 USD, which was outside of the total period. These results are in parallel finding with those obtained by Pata (Pata, 2018c) (Pata, 2018a) (Pata, 2018b) for urkey and Zhang et al. (Zhang et al., 2019) for 121 different countries out of which 108 countries did not reach for the turning point.

Therefore, to overcome all these concerning difficulties, policymakers should design policies which include (i) increase of per capita income for people, (ii) plan for new manufacturing industries with the less polluting environment and locality (iii) controlled and planned development of urban areas with guidance and learning awareness institutions for an efficient and sustainable society (iv) less polluting energies mixture usage models for industry, transportation, and other necessary key areas concerning environment with sustainable growth. Finally, when this study was carried out, coal consumption was not incorporated into the mode 1 due to the model stability issue with the ARDL bounds testing approach.

\section{Declaration of conflict of interests}


The authors declared no potential conflicts of interest with respect to the research, authorship, and/or publication of this article.

\section{References}

Ahmad, N. et al. (2017) 'Modelling the CO2 emissions and economic growth in Croatia: Is there any environmental Kuznets curve?', Energy. Elsevier Ltd, 123, pp. 164-172. doi: 10.1016/j.energy.2016.12.106.

Ahmed, K. (2017) 'Revisiting the role of financial development for energy-growth-trade nexus in BRICS economies', Energy. Elsevier Ltd, 128, pp. 487-495. doi: 10.1016/j.energy.2017.04.055.

Akbostanci, E., Türüt-Aşik, S. and Tunç, G. I. (2009) 'The relationship between income and environment in Turkey: Is there an environmental Kuznets curve?', Energy Policy, 37(3), pp. 861-867. doi: 10.1016/j.enpol.2008.09.088.

Al-Mulali, U. and Ozturk, I. (2016) 'The investigation of environmental Kuznets curve hypothesis in the advanced economies: The role of energy prices', Renewable and Sustainable Energy Reviews. Elsevier, 54, pp. 1622-1631. doi: 10.1016/j.rser.2015.10.131.

Allard, A. et al. (2018) 'The N-shaped environmental Kuznets curve: an empirical evaluation using a panel quantile regression approach', Environmental Science and Pollution Research. Springer, 25(6), pp. 5848-5861.

Antonakakis, N., Chatziantoniou, I. and Filis, G. (2017) 'Energy consumption, CO2 emissions, and economic growth: An ethical dilemma', Renewable and Sustainable Energy Reviews. Elsevier, 68(September 2016), pp. 808-824. doi: 10.1016/j.rser.2016.09.105.

Asian Development Bank (ADB) (2017) Climate Change Operational Framework 2017-2030: Enhanced Actions for Low Greenhouse Gas Emissions and Climate-Resilient Development. 
Available at: http://dx.doi.org/10.22617/TCS178947-2.

Baek, J. (2016) 'Do nuclear and renewable energy improve the environment? Empirical evidence from the United States', Ecological Indicators. Elsevier Ltd, 66, pp. 352-356. doi: 10.1016/j.ecolind.2016.01.059.

Bank, W. (2017) Atlas of Sustainable Development Goals 2017: From World Development Indicators. The World Bank.

Bilgili, F., Koçak, E. and Bulut, Ü. (2016) 'The dynamic impact of renewable energy consumption on CO2 emissions: A revisited Environmental Kuznets Curve approach', Renewable and Sustainable Energy Reviews. Elsevier, 54, pp. 838-845. doi: 10.1016/j.rser.2015.10.080.

Bölük, G. and Mert, M. (2014) 'Fossil \& renewable energy consumption, GHGs (greenhouse gases) and economic growth: Evidence from a panel of EU (European Union) countries', Energy, 74(C), pp. 439-446. doi: 10.1016/j.energy.2014.07.008.

'BP Statistical Review of World Energy Statistical Review of World' (2019) The Editor BP Statistical Review of World Energy. Available at: https://www.bp.com/content/dam/bp/businesssites/en/global/corporate/pdfs/energy-economics/statistical-review/bp-stats-review-2019-fullreport.pdf.

Chen, Y., Wang, Z. and Zhong, Z. (2019) 'CO 2 emissions, economic growth, renewable and non-renewable energy production and foreign trade in China', Renewable Energy. Elsevier Ltd, 131, pp. 208-216. doi: 10.1016/j.renene.2018.07.047.

Danish et al. (2017) 'Role of renewable energy and non-renewable energy consumption on EKC: Evidence from Pakistan', Journal of Cleaner Production. Elsevier Ltd, 156, pp. 855-864. doi: 10.1016/j.jclepro.2017.03.203. 
David I, S., Michael, C. S. and Edward, B. B. (1996) 'Economic Growth and Environmental Degradation: The Environmental Kuznets Curve and Sustainable Development', World Development, 24(7), pp. 1151-1160.

Dickey, D. A. and Fuller, W. A. (1981) 'Likelihood Ratio Statistics for Autoregressive Time Series with a Unit Root', Econometrica. [Wiley, Econometric Society], 49(4), pp. 1057-1072. doi: $10.2307 / 1912517$.

Dinda, S. (2004) 'Environmental Kuznets Curve hypothesis: A survey', Ecological Economics, 49(4), pp. 431-455. doi: 10.1016/j.ecolecon.2004.02.011.

Dogan, E. and Inglesi-Lotz, R. (2017) 'Analyzing the effects of real income and biomass energy consumption on carbon dioxide (CO2) emissions: Empirical evidence from the panel of biomassconsuming countries', Energy. Elsevier B.V., 138, pp. 721-727. doi: 10.1016/j.energy.2017.07.136.

Dong, K., Sun, R. and Hochman, G. (2017) 'Do natural gas and renewable energy consumption lead to less $\mathrm{CO} 2$ emission? Empirical evidence from a panel of BRICS countries', Energy. Elsevier B.V., 141, pp. 1466-1478. doi: 10.1016/j.energy.2017.11.092.

Fodha, M. and Zaghdoud, O. (2010) 'Economic growth and pollutant emissions in Tunisia: An empirical analysis of the environmental Kuznets curve', Energy Policy. Elsevier, 38(2), pp. 1150-1156. doi: 10.1016/j.enpol.2009.11.002.

Friedl, B. and Getzner, M. (2003) 'Determinants of CO2 emissions in a small open economy', Ecological Economics, 45(1), pp. 133-148. doi: 10.1016/S0921-8009(03)00008-9.

Gokmenoglu, K. K. and Taspinar, N. (2018) 'Testing the agriculture-induced EKC hypothesis: the case of Pakistan', Environmental Science and Pollution Research. Environmental Science and Pollution Research, 25(23), pp. 22829-22841. doi: 10.1007/s11356-018-2330-6. 
Grossman, G. M. and Krueger, A. B. (1991) Environmental impacts of a North American free trade agreement. National Bureau of economic research.

Hanif, I. (2017) 'Economics-energy-environment nexus in Latin America and the Caribbean', Energy. Elsevier B.V., 141, pp. 170-178. doi: 10.1016/j.energy.2017.09.054.

Hill, R. J., Magnani, E. and Hill, R. (1955) 'an Exploration of the Conceptual and Empirical Basis of the Environmental Kuznets Curve', Kuznets, (1955).

Ibrahim, M. H. and Law, S. H. (2014) 'Social capital and CO2 emission - Output relations: A panel analysis', Renewable and Sustainable Energy Reviews. Elsevier, 29, pp. 528-534. doi: 10.1016/j.rser.2013.08.076.

IRENA, I. R. A. (2016) 'Renewable energy in cities', International Renewable Agency: Abu Dhabi, UAE.

Jayanthakumaran, K., Verma, R. and Liu, Y. (2012) 'CO 2 emissions, energy consumption, trade and income: A comparative analysis of China and India', Energy Policy. Elsevier, 42(June 2011), pp. 450-460. doi: 10.1016/j.enpol.2011.12.010.

Kasman, A. and Duman, Y. S. (2015) 'CO2 emissions, economic growth, energy consumption, trade and urbanization in new EU member and candidate countries: A panel data analysis', Economic Modelling. Elsevier B.V., 44, pp. 97-103. doi: 10.1016/j.econmod.2014.10.022.

Kim, K. and Schmidt, P. (1990) 'Some evidence on the accuracy of Phillips-Perron tests using alternative estimates of nuisance parameters', Economics Letters, 34(4), pp. 345-350. doi: 10.1016/0165-1765(90)90143-O.

Lau, L. S., Choong, C. K. and Eng, Y. K. (2014) 'Investigation of the environmental Kuznets curve for carbon emissions in Malaysia: DO foreign direct investment and trade matter?', Energy Policy. Elsevier, 68, pp. 490-497. doi: 10.1016/j.enpol.2014.01.002. 
Lindmark, M. (2002) '1-s2.0-S0921800902001088-main.pdf’, 42, pp. 333-347.

Malik, M. Y. et al. (2020) 'Symmetric and asymmetric impact of oil price, FDI and economic growth on carbon emission in Pakistan: Evidence from ARDL and non-linear ARDL approach',

Science of the Total Environment. Elsevier B.V, 726, p. 138421. doi: 10.1016/j.scitotenv.2020.138421.

Maneejuk, N. et al. (2020) 'Does the Environmental Kuznets Curve Exist? An International Study’, Sustainability. Multidisciplinary Digital Publishing Institute, 12(21), p. 9117.

Mirza, F. M. and Kanwal, A. (2017) 'Energy consumption, carbon emissions and economic growth in Pakistan: Dynamic causality analysis', Renewable and Sustainable Energy Reviews. Elsevier Ltd, 72(October 2016), pp. 1233-1240. doi: 10.1016/j.rser.2016.10.081.

Morse, S. and Morse, S. (2019) 'Environmental Performance Index', The Rise and Rise of Indicators, pp. 102-123. doi: 10.4324/9781315226675-5.

Moutinho, V., Varum, C. and Madaleno, M. (2017) 'How economic growth affects emissions? An investigation of the environmental Kuznets curve in Portuguese and Spanish economic activity sectors', Energy Policy. Elsevier Ltd, 106(April), pp. 326-344. doi: 10.1016/j.enpol.2017.03.069.

Narayan, P. K. (2005) 'The saving and investment nexus for China: evidence from cointegration tests', Applied Economics. Routledge, 37(17), pp. 1979-1990. doi: 10.1080/00036840500278103.

Narayan, P. K. and Smyth, R. (2006) 'What determines migration flows from low-income to high-income countries? An empirical investigation of Fiji-U.S. migration 1972-2001', Contemporary Economic Policy, 24(2), pp. 332-342. doi: 10.1093/cep/byj019.

Nasir, M. and Ur Rehman, F. (2011) 'Environmental Kuznets Curve for carbon emissions in 
Pakistan: An empirical investigation', Energy Policy. Elsevier, 39(3), pp. 1857-1864. doi: 10.1016/j.enpol.2011.01.025.

Nasreen, S., Anwar, S. and Ozturk, I. (2017) 'Financial stability, energy consumption and environmental quality: Evidence from South Asian economies', Renewable and Sustainable Energy Reviews, 67, pp. 1105-1122. doi: 10.1016/j.rser.2016.09.021.

Nizamani, R. A. et al. (2021) 'Dynamic Influences of Urbanization, Economic Expansion and Primary Energy Consumption on Carbon Dioxide Emissions in Pakistan', International Journal on Emerging Technologies, 12(2), pp. 171-176.

Panayotou, T. (1993) Empirical tests and policy analysis of environmental degradation at different stages of economic development. International Labour Organization.

Pao, H. T. and Tsai, C. M. (2010) 'CO2 emissions, energy consumption and economic growth in BRIC countries', Energy Policy. Elsevier, 38(12), pp. 7850-7860. doi: 10.1016/j.enpol.2010.08.045.

Pata, U. K. (2018a) 'Renewable energy consumption, urbanization, financial development, income and $\mathrm{CO} 2$ emissions in Turkey: Testing EKC hypothesis with structural breaks', Journal of Cleaner Production. Elsevier Ltd, 187, pp. 770-779. doi: 10.1016/j.jclepro.2018.03.236.

Pata, U. K. (2018b) 'The effect of urbanization and industrialization on carbon emissions in Turkey: evidence from ARDL bounds testing procedure', Environmental Science and Pollution Research. Environmental Science and Pollution Research, 25(8), pp. 7740-7747. doi: 10.1007/s11356-017-1088-6.

Pata, U. K. (2018c) 'The influence of coal and noncarbohydrate energy consumption on CO2 emissions: Revisiting the environmental Kuznets curve hypothesis for Turkey', Energy. Elsevier Ltd, 160, pp. 1115-1123. doi: 10.1016/j.energy.2018.07.095. 
Pesaran, M. H. and Shin, Y. (1995) 'An autoregressive distributed lag modelling approach to cointegration analysis'. Department of Applied Economics, University of Cambridge Cambridge. Pesaran, M. H., Shin, Y. and Smith, R. J. (2001) 'Bounds testing approaches to the analysis of level relationships', Journal of Applied Econometrics, 16(3), pp. 289-326. doi: 10.1002/jae.616.

Rafique, M. M. and Rehman, S. (2017) 'National energy scenario of Pakistan - Current status, future alternatives, and institutional infrastructure: An overview', Renewable and Sustainable Energy Reviews, 69(November 2016), pp. 156-167. doi: 10.1016/j.rser.2016.11.057.

Rahu, M. A. et al. (2020) 'Decomposition and Decoupling Analysis of Electricity Consumption in Pakistan', International Journal on Emerging Technologies, 11(5), pp. 713-723.

Saboori, B., Sulaiman, J. and Mohd, S. (2012) 'Economic growth and CO 2 emissions in Malaysia: A cointegration analysis of the Environmental Kuznets Curve', Energy Policy. Elsevier, 51, pp. 184-191. doi: 10.1016/j.enpol.2012.08.065.

Schwert, G. W. (2002) ‘Tests for Unit Roots', Journal of Business \& Economic Statistics. Taylor \& Francis, 20(1), pp. 5-17. doi: 10.1198/073500102753410354.

Shafik, N. and Bandyopadhyay, S. (1992) Economic growth and environmental quality: timeseries and cross-country evidence. World Bank Publications.

Shahbaz, M. et al. (2020) 'A nonparametric analysis of energy environmental Kuznets Curve in Chinese Provinces', Energy Economics. Elsevier B.V, 89, p. 104814. doi: 10.1016/j.eneco.2020.104814.

Shahbaz, M., Lean, H. H. and Shabbir, M. S. (2012) 'Environmental Kuznets Curve hypothesis in Pakistan: Cointegration and Granger causality', Renewable and Sustainable Energy Reviews. Elsevier Ltd, 16(5), pp. 2947-2953. doi: 10.1016/j.rser.2012.02.015.

Shukla, V. and Parikh, K. (1992) 'THE ENVIRONMENTAL CONSEQUENCES OF URBAN 
GROWTH: CROSS-NATIONAL PERSPECTIVES ON ECONOMIC DEVELOPMENT, AIR POLLUTION, AND CITY SIZE', Urban Geography. Routledge, 13(5), pp. 422-449. doi: 10.2747/0272-3638.13.5.422.

Sinha, A., Shahbaz, M. and Balsalobre, D. (2018) 'N-shaped environmental Kuznets curve: a note on validation and falsification'.

Stern, D. I., Common, M. S. and Barbier, E. B. (1996) 'Economic growth and environmental degradation: the environmental Kuznets curve and sustainable development', World development. Elsevier, 24(7), pp. 1151-1160.

Sugiawan, Y. and Managi, S. (2016) 'The environmental Kuznets curve in Indonesia: Exploring the potential of renewable energy', Energy Policy. Elsevier, 98, pp. 187-198. doi: 10.1016/j.enpol.2016.08.029.

Terrell, T. (2020) 'Carbon Sequestration and N-and M-Shaped Environmental Kuznets Curves: Evidence from International Land Use Change', Available at SSRN 3461033.

Zhang, Y. et al. (2019) 'The environmental Kuznets curve of CO 2 emissions in the manufacturing and construction industries: A global empirical analysis', 79(June). doi: 10.1016/j.eiar.2019.106303. 